ISSN 2078-6441. Вісник Львівського університету. Серія географічна. 2013. Випуск 42. С. 274-282. Visnyk of the Lviv University. Series Geography. 2013. Issue 42. P. 274-282.

338.488.2:640.4

\author{
гор ндяк \\ ьвівський н ціон льний університет імені в н \\ вул. . орошенк 41, м. ввів, 79000, кр їн
}

ро н лізов но історію ст новлення і розвитку туристських притулків у хідних рп т х у другій половині ст.-1939 р. озглянуто роль укр їнських т польських туристичних орг ніз цій у розбудові інфр структури розміщення подорожніх уздовж гірських м ршрутів хідної личини. иявлено х р ктерні риси орг ніз ції розбудови, обл штув ння і обслуговув ння в туристських притулк $\mathrm{x}$.

лючові слов : інфр структур розміщення туристів, туристські притулки, туристські м ршрути, туристські тов риств .

ерші туристські притулки в гор х т їхні прототипи виникли у вропі в середині

ст. рхітектурою вони н г дув ли сільські будинки, для їхнього спорудження використовув ли к мінь бо дерево, розт шовув ли їх у відд лених від поселень високогірних $\mathrm{p}$ йон х.

ояв гірських туристських притулків у вропі зумовлен соці льно-економічними процес ми. рб ніз ція, підвищення ролі міст, промисловості, сфери послуг зумовили серед міського н селення потребу періодичного відпочинку й оздоровлення поз містом у природних тр кціях. літним для європейців ст в відпочинок у гор х. ількість рекре нтів постійно збільшув л сь декв тно до збільшення міського н селення й погіршення екологічних умов, серед н селення формув л ся екологічн культур , усвідомлення здорового способу життя. озвиток тр нспортного сполучення, н с мперед з лізничного, поліпшив доступ до рекре ційних територій. ля відпочинку серед природних тр кцій необхідно було розвив ти інфр структуру розміщення м ндрівників і рекре нтів - виникли вілли, с н торії, п нсіон ти, притулки н гірських туристських м ршрут х.

ьогодні ктивний розвиток туризму в кр їнських рп т х без держ вної стр тегії розвитку регіону, з умов фін нсового дефіциту, отже, без імовірних зн чних держ вних к піт ловкл день у розвиток туризму н цій території в н йближчій перспективі не очікують. ому пост є проблем визн чення передумов і перспектив розвитку туризму рп тського регіону із з лученням н явних природних т історикокультурних об'єктів, ур ховуючи попередній досвід розвитку туризму з ініці тиви професійних орг ніз цій, що в перспективі д сть змогу об'єктивно т $р$ ціон льно створюв ти туристичну інфр структуру. кр їні є можливості створити суч сну інфр структуру, як б відповід л світовим ст нд рт м, проте іï ре ліз ція потребує комплексного н укового підходу і держ вної підтримки н рівні з конод вств .

кту льність дослідження зумовлен необхідністю вивчення історичного досвіду розвитку туристичної інфр структури високогірних р йонів кр їнських рп т для

(C) НДяк ., 2013 
створення сьогодні комфортних і безпечних умов відпочинку т рекре ції туристів, які подорожують по гірській місцевості. едост тнє інфр структурне освоєння, зокрем відсутність суч сних з кл дів розміщення в орг ніз ції туристично-рекре ційної діяльності, $\epsilon$ нег тивним чинником, що г льмує розвиток туризму кр їнських $\quad$ рп т. ш мет - про н лізув ти суспільно-політичні, економіко-геогр фічні передумови формув ння і розвитку туристських притулків у хідних

$-\mathrm{H}$ ПОч ТКУ ст.

ктивний розвиток рекре ції т туризму у хідній личині в середині

-н поч тку ст. - свідчення позитивних тенденцій суспільно-економічного розвитку регіону в скл ді встрійської, згодом встро- горської т ольської держ в. еред в жливих передумов цього процесу - унік льні природні т етногр фічні особливості рп т, територія прив блюв л подорожніх незн чним з селенням т бул м йже недослідженою. росторов близькість т спільн історія з держ в миметрополіями, де н поч тку ст. серед з можної інтелігенції були сформов ні тр диції орг нізовув ти подорожі, з йм тись лижним спортом, оздоровленням, сприял прибуттю б г тьох н уковців, урядовців, досвідчених м ндрівників.

екре ція і туризм у рп т х ст ли в жливим чинником соці льно-економічного розвитку, джерелом доходів місцевого н селення. оселення - центри рекре ції і туризму - серед інших виділялись ліпшими соці льно-економічними умов ми розвитку. роте з г льний розвиток інфр структури в рп т х був н низькому рівні- нез довільний ст н доріг, не прокл дено туристських м ршрутів, зовсім нерозвинен сфер гостинності - 3 кл ди х рчув ння, розміщення. езв ж ючи н з зн чені недоліки, туризм т рекре ція розвив лися інтенсивно, про це свідчить зН чн кількість рекл мно-інформ ційних м тері лів, вид них у другій половині

-н поч тку ст. крім путівників, буклетів, проспектів, к рт, у ході вивчення розвитку туристських притулків використ но оригін льні м тері ли тогоч сної преси т н уково-популярні пр ці рекре нтів.

ктивному розвитку туризму і рекре ції у хідних рп т х сприял тогоч сн вл д , з цік влен в господ рському освоєнні гірської території, вивченні ії ресурсів, вон орг ніз ційно підтримув л пізн в льні т оздоровчі подорожі, фін нсув л прокл д ння з лізниць, будівництво мостів; 3 сприяння місцевих дміністр цій зн кув ли туристські м ршрути, під будівництво н д в ли земельні ділянки. окрем , суттєво ктивізув ло розбудову інфр структури рекре ції у гор х прокл д ння з лізниці т нісл вів- ороненк . крім туристських б 3, у орохті, ременцях, икуличині, мній т ремчі побудов но зн чну кількість вілл і п нсіон тів для м ндрівників і відпочив льників. орічно ці 3 кл ди розміщення відвідув ло до 10 тис. осіб.

гомим чинником розвитку інфр структури розміщення туристів у хідних $\mathrm{p}$ п т х було утворення гром дських орг ніз цій, які ктивізув ли м ндрівки, оздоровлення, н уково-пізн в льну т спортивну роботу, н с мперед, серед молоді - студентів і учнів. 1873 p. у р кові створено тр нське тов риство ( ), Згодом, у 1876-1878 pр. відкрито його відділення у т нісл вові т оломиї. крім польського тов риств , діяли й укр їнські, зокрем , кр їнське туристично-кр єзн вче тов риство “ л й” т рп тський лещет рський клуб.

ром дські орг ніз ції зн кув ли туристські м ршрути, прокл д ли їх н прям ми з безпечними умов ми т м льовничими кр євид ми для втономних м ндрівок. ерше зн кув ння м ршруту проведено 1878 р. н орногорі. рокл д ння туристських 
м ршрутів зумовило згодом необхідність створення інфр структури з розміщення туристів - туристських притулків.

тже, упродовж нетрив лого ч су зусиллями нечисленних м торів у м лоз селеному т нез безпеченому інфр структурою регіоні вд лося створити розвинену мережу туристських притулків т ст нцій, пром ркув ти туристські м ршрути, популяризув ти лижний спорт, вид ти зн чну кількість туристично-популярних м тері лів - путівників, брошур, к рт.

сторичні особливості розвитку інфр структури розміщення туристів в укр їнській туристично-кр єзн вчій літер турі досліджено недост тньо. сновний обсяг інформ ції про ст новлення туристичної інфр структури другої половини -поч тку ст. відобр жений у н уково-популярних, періодичних джерел х поч тку ст. еред історичних джерел у дослідженні використ но пр ці вторів поч тку ст. . ехм н [6], . онсьоровського [7], . онтня [8], . гірного [1], пр ці суч сних дослідників - . плон [2], . л пчук [3], . уцького [4], . вчук [5] т ін.

охопленому переліку пр ць про н лізов но розвиток туристичної інфр структури

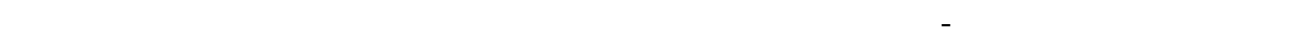
н ведено комплексну х р ктеристику історії подорожей г лицької інтелігенції, студентської молоді, опис унік льних фольклорно-етногр фічних т природних особливостей гірської ч стини хідної личини, проте окремих досліджень інфр структури розміщення туристів не проводили.

ерші туристські подорожі хідними рп т ми орг нізовув ли у 20-30-х рок х

ст. м тори осібно бо невеликими груп ми, н с мперед поляки. ише в другій половині ст. у хідній личині виникли перші туристські тов риств , зусиллями яких орг нізов но подорожі т обл штов но туристичну інфр структуру. ояв туристських тов риств у хідній личині з ч сом збіг ється з іншими кр їн ми, вони м ли відповідники серед н ціон льних гром д регіону - укр їнської, н йбільше польської.

ершу туристську подорож т описи хідних рп т - природи, етногр фічних особливостей гуцулів, здійснив лєкс ндр в дзький (1798-1868), у цей же ч с б г то подорожув в рп т ми л дисл в уйцицький (1807-1879). сто з пізн в льною метою подорожув ли львівські літер тори ч сопису “Ziewonia” i "Dziennik Mód Paryskich". н уковою т рекре ційною метою орг нізовув ли подорожі професори ьвівського університету - бот нік іоцинт оборжевський і інцент оль - перший дослідник рельєфу долини рік ністр , трию, пору, вічі, імниці, орного і ілого еремошів. н чні дослідження хідних рп т провели вгуст ельовський т професор геллонського університету юдвік етрусінський, його вв ж ють першим професійним туристом.

хідн личин бул попереду в орг ніз ції туристського руху в меж х тодішньої ольщі т території теперішньої кр їни. ут сформув лися діячі, які у н укових ст ттях, популярних н рис х зуміли з кл сти н укове підгрунтя розвитку туризму створення туристських тов риств, обл штув ння туристичної інфр структури.

окрем , н прями діяльності й основні $з$ вд ння тр нського тов риств були різносторонніми й н с мперед спрямов ними н дослідження розвитку туризму т рекре ції, вивчення рп т, популяриз ції інформ ції про відпочинок у гор х, охорону природи, розвиток різних форм гірського господ рств рп т. еред першочергових 3 вд нь ов риств - “скерув ти туристичний бум н орногору із побудовою т м схроніск (туристських притулків), д ти бідному гуцульському люду більшого з робітку 
через розвиток дрібного промислу, врешті перед ти н уковій гром дськості результ ти спр вді невідомого регіону, як з природної т к й етногр фічної цінності” [2, с. 184].

ерший туристський притулок $з$ поч ткув ло орногірське відділення тр нського тов риств ( оломия) у 1878 р. н полонині джин і присвоїло ім'я н регорович з служеного діяч в розвитку туризму. ритулок збудув в своїм коштом вл сник полонини в н опівчук. удинок скл д вся з трьох кімн т, дві з яких призн чені для туристів, комори т сіней. імн ти обігрів л спільн, розт шов н між ними піч.

1879-1881 pр. біля оверли в урочищі росляк н місці колиби п стухів т нісл вське відділення побудув ло притулок імені енріх оффб уер . ритулок виявився популярним серед туристів, оскільки був поч тковим пунктом для походів орногорою. 1908 р. притулок знищений пожежею.

ля безпеки й орієнтув ння туристські м ршрути зн кув ли з прикл дом у тр х кольоровими смужк ми подібно до суч сних методів. ерше зн кув ння у рп т х провели 1880 р. енріх оффб уер т остянтин івицький, які озн кув ли перший туристський м ршрут до притулку в урочищі джин . 1904 р. вони пром ркув ли м ршрут орохт - укул- озьнєск -притулок росляк.

1880 р. відділ отрим в земельну ділянку в сені для побудови притулку в урочищі оливне під горою іп- в н, який відкрито 1882 p.

1923-1927 рр. притулок н росляку відновлено, він ст в н йбільшим у рп т х, був розр хов ний н 120 місць для ночівлі (перед війною місць збільшили до 150), м в н йкр ще обл штув ння, пропонув в усі зручності - душ, електричне освітлення, телефонний зв'язок, простору вер нду. рожив ння було пл тним - три з половиною злоті 3 перший день т три злоті 3 н ступні дні (узимку дод тково спл чув ли 30 грошей 3 оп лення), член м тр нського тов риств н д в ли $50 \%$ знижки. ритулок сп лено в роки ругої світової війни, н його місці сьогодні є спортивн 63 “ росляк”.

уристські притулки будув ли з кошти тов риств , які н дходили від членів тов риств як членські внески, і від комерційної діяльності. окрем , оломийський відділ у 1886 р. н лічув в 67 членів і 3 йм вся головно утрим нням місцевого ринку 3 прод жу виробів н родного рукоділля. роблені кошти скеровув ли н будівництво притулку в б'є, який з вершено у 1892 р., т перебудову притулку під горою іпв н, сум збору бул незн чною - 1 злотий.

ісля смерті рцелія мінович, керівник т нісл вського відділу тр нського тов риств , 31892 р. діяльність тов риств припинил сь. ого ж року притулок н росляку, що був під опікою т нісл вського відділу, перейшов під упр вління орногірського відділу. 1894 р. орногірський відділ придб в з 800 злотих споруду у орохті, яку пл нув ли під притулок. я купівля спричинил фін нсову скруту і спонук л відділ звернутись до керівництв ов риств 3 прох нням про допомогу в 3 вершенні обл штув ння притулку, у 1895 р. відділ отрим в - 100 злотих.

еобхідність у розширенні розбудови туристичної інфр структури н прикінці ст. бул зумовлен зн чною кількістю туристів. 1896 р. кількість тих, хто 6 ж в розміститися у притулку орохти, ст новил 150 осіб, у б’є 305.

годом орногірський відділ охопив діяльністю території оломийського, осівського, нятинського, т нісл вського, луського, олинського i огородч нського повітів. іяльність н зн чній і не з безпеченій туристичною інфр структурою території не можн було вести лише н вл сні кошти. 1896 р. відділ повторно звернувся до керівництв ов риств з прох нням про фін нсову допомогу в обсязі 
2 тис. злотих для обл штув ння будинку відпочинку у б'є, будівництв з лізничної ст нції у орохті, ремонту притулку н росляку і ришевській. роте коштів н широком сшт бну розбудову у ов ристві не було.

сткову допомогу н розбудову туристської інфр структури н д в ли мецен ти, м тори подорожей т відпочинку. окрем, у будівництві притулку н ришевській допоміг деякий еопольд ьєверж.

1895 р. орногірський відділ ов риств н лічув в 142 предст вник, які спл чув ли членські внески. е м ючи зн чних фін нсів, проте усвідомлюючи свою місію сприяння доступності гір для туристів, відділ розпоч в будівництво притулку н

ришевській. 1896 р., після купівлі ще одного будинку у орохті, кількість туристів, які могли скорист тись об’єкт ми відділу, збільшил сь. 1898 р. відділ з г лом прийняв 913 осіб (у орохті - 671 особу, у б'є - 242), що свідчило про зн чне збільшення кількості туристів у рп т х.

огляду н зн чну прив бливість туристичної інфр структури рп т центр льне упр вління ов риств 1901 р. з довольнило прох ння орногірського відділу і н д ло йому допомогу в сумі 6,6 тис. корон, т кож ліквідув ло його борг у сумі 967 корон. продовж н ступних років для розвитку туристичної інфр структури у хідних

рп т х орногірський відділ отрим в дозвіл з лиш ти в своєму розпорядженні ч стину з роблених коштів. оліпшення фін нсового ст ну позн чилось не тільки н розбудові притулків, відділ здійснив м ркув ння м ршрутів 3 орохти н ічеру i укул, 3 ремчі - н вірник, орг н, орногірчик, ковицю, скелі овбуш , елику окету зі вст новленням зн чної кількості вк зівників.

ісля 1905 р. у ьвівському університеті виникл спілк - к демічний туристський клуб ( ), як пл нув л орг нізовув ти м ндрівки 3 метою н укового дослідження, проведення пр ктичних з нять 3 туризму в околицях ьвов т в хідних

рп т х. Г лом події 1905 р. зумовили сповільнення розвитку туристських м ндрівок т труднощі в розвитку туристичної інфр структури. одноч с репресії щодо поляків у осійській імперії спричинили зн чну емігр цію в личину польської молоді. еред прибулих до ьвов бул зн чн кількість уч сників ищих в к ційних курсів, які у 1904-1905 рр. проходили у коп ному, метою яких було відпр цюв ння пр ктичних н виків 3 ктивних видів туризму. середок продовжув в 3 йм тись ктивним туризмом, орг нізовув в виїзди для н вч нь туризму в три й водноч с пл нув в орг ніз цію кр єзн вчих досліджень околицями ьвов $\mathrm{T}$ туристських подорожей у хідні рп ти. літку 1906 р. орг нізов но 14 м ндрівок околицями ьвов, у ескиди, орногору. одорожі н були зн чного розголосу, їх широко висвітлюв ли у пресі, що сприяло зрост нню їхньої популярності.

1907 p. н лічув в 158 уч сників, які н вч лись у різних львівських н вч льних 3 кл д х. еред уч сників подорожей, окрім поляків, були й студенти-укр їнці. літку 1909 р. груп з 15 осіб лубу провел першу м ндрівку неосвоєними м ршрут ми орг нів. кінець 1909 р. луб н лічув в уже 374 члени - н йбільш кількість його уч сників $з$ весь ч с існув ння. годом, у 1911 р., соці льно-економічні проблеми в держ ві, т кож перехід ч стини членів лубу в інші орг ніз ції - тр нське тов риство, рп тське лещет рське тов риство, ольське кр єзн вче тов риство зумовили зниження його ктивності.

прикінці ст. інтенсивно розвив лися різні форми лижного спорту, зокрем , лижні туристські походи. хідних рп т х лижні туристські подорожі з поч ткув в деуш моляховський 1893 p. т рові м тор ми лижних подорожей були зеф 
н йдер і рі н л шинський. зимку 1897 р. зеф $\quad$ н йдер у скл ді невеликої групи вперше зійшов н оверлу.

годом інтерес до зимових лижних подорожей у доволі зн чної групи туристів зумовив створення у ьвові уристського лещет рського клубу ( ). о ершої світової війни пр цюв в особливо успішно - він орг нізовув в туристські подорожі, проводив зн чну популяриз ційну й інструкторську роботу, вид в в н вч льну літер туру з користув ння лиж ми, відкрив відділи у еремишлі i $p$ кові (1908). еред поч тком ершої світової війни у лубі н лічув лося 403 предст вники.

роведення регулярних подорожей для великих груп у рп ти зумовлюв ло необхідність створення б зи для ночівлі в гор х. езв ж ючи н туристський досвід i зн чну територію охоплення, ухв лено для широкої проп г нди лижного туризму орг нізув ти 6 зу в місці, близькому і легкодоступному до ьвов - с. л вське.

поч тк х у л вському керівництво лубу домовилось у прив тному секторі про місця для ночівлі, 31910 р. розпоч то будівництво вл сного притулку. ей притулок функціонув в до ершої світової війни (під ч с війни зруйнов ний).

жовтні 1919 р. відбувся перший з г льний збір , н якому серед першочергових $з$ вд нь бул відбудов туристського притулку в л вському. 1923 р. новий притулок відкрили, що сприяло ктивіз ції соці льно-економічного розвитку н вколишньої території. продовж короткого ч су л вське ст ло відомим центром не тільки зимового, й літнього відпочинку.

ьвівський відділ ольського тр нського тов риств ( , н ступник тр нського тов риств ) після ершої світової війни продовжив ктивну діяльність у рп т х. 1922 р. він уже н лічув в 134 члени, орг нізув в шість м сових подорожей у три, орг ни i орногору. ерівництво пл нув ло розгорнути мережу притулків у гірській ч стині, проте фін нсові труднощі не сприяли ре ліз ції пл нів.

вересні 1923 р. створено орг ніз ційний комітет з відновлення діяльності т нісл вського відділу . ктивіз ція в діяльності сприял пл номірному розвитку туристичної інфр структури у хідних рп т $\mathrm{x}$ - розбудові туристських притулків т обл штув нні туристських м ршрутів.

ініці тиви д м енкевич 1925 р. розпоч то будівництво притулку в хідних орг н х, в околицях смолоди. ля його будівництв підготовлено документ цію т звернення до іністерств гром дських робіт і іністерств рільництв про н д ння допомоги. одноч с при воєводському уряді у ьвові т т нісл вові створено воєводські комісії для сприяння розвитку туристської інфр структури.

н слідок спільних дій гром дських орг ніз цій т місцевої дміністр ції у 1927 р. ьвівський відділ відкрив туристський притулок н лі, у долині ріки імниця; т нісл вський відділ з вершив ремонт притулку н росляку під оверлою. 1928 р. звернулося до місцевої дміністр ції щодо відбудови дороги з орохти долиною руту, т кож побудови з лізничної колії в долині еремошу. ього ж року ьвівський відділ пром ркув в туристські м ршрути з долини річки олод н оп дю т 3 смолоди до притулку в лі. т нісл вський відділ обл штув в туристський м ршрут від росляк до оверли.

йбільший розвиток туристичної інфр структури у хідних рп т х прип в н 30-ті роки ст. уристські тов риств 3 ктивної підтримки польського уряду т місцевої дміністр ції інтенсивно розбудовув ли інфр структуру розміщення туристів. уттєвим поштовхом було проведення 3 тр вня 1930 р. зборів хіднобескидської 
комісії, що охоплюв л предст вників усіх відділів . омісія погодил обл штув ння і добудову н явних, будівництво нових туристських притулків у йф йловій ( истриця), долині вічі, уркуті, н еликому ерху, т кож туристської ст нції у оревці під ивулею.

1931 р. філія т нісл вського відділу відкрил туристський притулок між гровцем і ивулею; у 1932 р. ьвівський відділ відкрив притулок біля витоків вічі. цей невеликий притулок н 17 місць вкл ло 30 тис. злотих. прикінці 1933 p. н схід від ишківського перев лу м ло 34 об'єкти для ночівлі.

т нісл вський відділ 1934 р. відкрив туристські притулки н блуницькому перев лі і під горою ом'як н 50 місць, під горою іп- в н, біля витоків ріки огорілець, н висоті пон д 1700 м - т кож н 50 місць.

30-х рок х ст. т кож долучилось до інфр структурного освоєння хідних рп т. 1936 р. збудов но н висоті 1370 м туристський притулок н південному схилі еликої ришевської. ритулок н три поверхи побудов но й обл штов но у гуцульському стилі. їд льні під пічк ми для декор ції використ но фризи з гуцульських к хлів, різьбою оздоблено стропові 6 лки.

продовж 1936-1937 pр. у притулку н еликій ришевській розмістилось пон д 3 тис. туристів. пільними зусиллями i ня декількох м ршрутів: орищенк - оверл -притулок н ришевській, истреньпритулок н ришевській-полян під омулом- джин - ришевськ . 1936 р. до притулку з орохти проведено телефон.

1935 р. створено відділ у осові, який до кінця року впорядкув в притулки в уркуті, під куповою, під бою ядовою, у оп динцю, н лт гулі. роте ці притулки не прив блюв ли зн чної кількості туристів і були неприбутковими. крім цього, відділ опікув вся шістьм туристськими ст нціями для ночівлі.

1935 р. відкрило туристський притулок під острицею. ритулок побудов но у стилі гуцульської гр жди, у внутрішньому обл штув нні використ но гуцульські меблі, пічки т к хлевий к мін. подібному стилі 1939 р. відкрито притулок н укулі. ьвівський відділ 1938 р. побудув в туристський притулок н ущині під ивулею н 34 місця.

1939 р. оломийський відділ розпоч в будівництво туристського притулку 3 цілорічним функціонув нням н полонині унчелик біля осм ч, який через поч ток ругої світової війни не був добудов ний.

кінець $1939 \mathrm{p} . \quad$ у хідних рп т х м ло 42 з кл ди розміщення туристів притулки і туристичні ст нції й опікув лося 1690 км гірських туристських стежок.

йбільше туристських притулків (98 \%) створено с ме польськими туристськими тов риств ми. кр їнські тов риств їх створюв ли зн чно пізніше - перший укр їнський туристський притулок відкрито лише 1934 р. у с. л вське. кр їнські тов риств дещо поступ лись перед польськими. е зумовлено ліпшими фін нсовими, орг ніз ційними можливостями серед поляків, польськ інтелігенція бул зн чно чисельнішою.

1939 р., з поч тком ругої світової війни діяльність туристських орг ніз цій у хідних рп т х з вершил ся. ійн з вд л зн чної шкоди туристській інфр структурі. ільшість туристських притулків знищено в ході бойових дій, незн чн ч стк вцілілих зруйнов н під ч с визвольних боїв

з військ ми 
1. гірний . моїх споминів / . гірний. - ьвів, 1935. - 70 с.

2. плон . сторія туризму й туристичного господ рств / . плон // ори уцульщини. - р ків, 2006. - . 183-196.

3. $л$ пчук . . уризм т відпочинок н уцульщині у другій половині XIX-першій третині ХХ століть / . . л пчук // кр їн : культурн сп дщин, н ціон льн свідомість, держ вність. - ьвів, 2008. - № 17. - . 80-87.

4. уцький . кр їнський кр єзн вчо-туристичний рух у личині (1830-1939рр.) / . уцький / [2-ге вид., доп.]. - в но- р нківськ: л й, 2003. - 140 с.

5. вчук. кр їнський л ст 1911-1939 рр. / . вчук. - в но- р нківськ: ілея- $\quad$ 1996. - 264 с.

6. Bachmann A. Dach w słowiańskim budownictwie ludowem / A. Bachmann // Sprawozdania Towarzystwa Naukowego we Lwowie. - Lwów : Towarzystwo Naukowe, 1929. - Dział 2; t. 5, z. 4. - 206 s.

7. Gqsiorowski H. Przewodnik po Beskidach Wschodnich. T. 2. Pasmo Czarnohorskie / H. Gąsiorowski. - Lwów; Warszawa : Ksią nica Atlas, 1933. - 560 s.

8. Kontny P. O księgach gruntowych osad górskich na Huculszczyźnie / P. Kontny // Sprawozdania Towarzystwa Naukowego we Lwowie. - Lwów, 1935. - R. 15, z. 3. S. 195-203.

m ття: н дійшл до ред кції 12.07.2013

доопр иьов н 16.08 .2013

прийнят до друку 10.10.2013

\section{ESTABLISHMENT AND DEVELOPMENT OF TOURIST SHELTERS IN THE EASTERN CARPATHIANS IN THE AUSTRO-HUNGARIAN AND POLISH PERIODS}

\section{Igor Pandyak}

Ivan Franko National University of Lviv, P. Doroshenko St., 41, UA - 79000 Lviv, Ukraine

History of establishment and development of tourist shelters in the Eastern Carpathians in the second half of the nineteenth century-1939 was analyzed. The role of Ukrainian and Polish tourism organizations in the development of infrastructure of placement travellers along mountain trails in Eastern Galicia was considered. The characteristic features of the development, construction and service of tourist shelters were detected.

Key words: infrastructure of tourist accommodation, tourist shelters, tourist routes, tourist societies. 


\section{горь ндяк}

ввовский н цион льный университет имени в н $\quad$ в нко,

$$
\text { ул. . орошенко, 41, 79000, ьвов, кр ин }
$$

ро н лизиров но историю ст новления и р звития туристических приютов в осточных

рп т х во второй половине ХІХ в.-1939 г. ссмотрено роль укр инских и польских туристических орг низ ций в р звитии инфр структуры р змещения туристов вдоль горных м ршрутов осточной лиции. ыявлено х р ктерные черты орг низ ции р звития, обустройств и обслужив ния в туристических приют х.

лючевые слов : инфр структур р змещения туристов, туристические приюты, туристические м ршруты, туристические обществ . 